\title{
Anaplasmataceae em gatos (Felis catus) no município de Campos dos Goytacazes, Rio de Janeiro ${ }^{1}$
}

\author{
Anderson B.T. Pinto ${ }^{2 *}$, Giane R. Paludo ${ }^{3}$, Gilberto S. Gazêta ${ }^{4}$, Mariana P.B. Jardim², \\ Marcela C. Scalon ${ }^{3}$, Arannadia B. Silva ${ }^{4}$ e Antonio P. Albernaz ${ }^{2}$
}

\begin{abstract}
Pinto A.B.T., Paludo G.R., Gazêta G.S., Jardim M.P.B., Scalon M.C., Silva A.B. \& Albernaz A.P. 2018. [Anaplasmataceae in cats (Felis catus) in the city of Campos dos Goytacazes, Rio de Janeiro.] Anaplasmataceae em gatos (Felis catus) no município de Campos dos Goytacazes, Rio de Janeiro. Pesquisa Veterinária Brasileira 38(6):1137-1150. Laboratório de Clínica e Cirurgia Animal, Hospital Veterinário, Universidade Estadual do Norte Fluminense Darcy Ribeiro, Av. Alberto Lamego 2000, Parque Califórnia, Campos dos Goytacazes, RJ 28013-602, Brazil. E-mail: andersonbtvet@gmail.com

In Brazil, by the year 2000, rickettsioses in domestic cats were little known and there were only sporadic reports of Ehrlichia sp. Recent research involving molecular biology and rickettsioses confirm the notion of the presence of theses agents in cats and show the need for more studies in Brazil. The objective of this paper was to characterize agents belonging to the Anaplasmataceae family that affect domestic cats and to clarify the importance of cats in the epidemiology of rickettsioses by molecular and serological methods associating the presence of disease with clinical and laboratory parameters. Blood samples were obtained from 60 healthy domestic cats. Blood count and serum biochemical tests were performed, and the data were registered. The samples were processed to obtain cell concentration and serum to perform the polymerase chain reaction (PCR) and the indirect immunofluorescence assay (IFA) respectively, in order to identify agents of the Anaplasmataceae family. The data were used for descriptive analysis to obtain frequencies and to perform non-parametric tests with the chi-square test ( $\mathrm{p} \leq 5 \%$ ), besides the laboratory findings of infection by Ehrlichia canis, Anaplasma phagocytophilum and Anaplasma platys. The results revealed that $33.33 \%$ of the agents belonged to the Anaplasmataceae family, $8.33 \%$ for E. canis, $20 \%$ for A. platys, and $10 \%$ for A. phagocytophilum. Serology samples were examined by indirect immunofluorescence to check samples reacting to A. phagocytophilum, with positive reaction of $8.33 \%$. The most frequent clinical and laboratory findings in patients positive for Anaplasmataceae agents were lethargy, enlargement of lymph nodes, pale mucous membranes, dehydration, thrombocytopenia, hyperglobulinemia and hypoalbuminemia. These data had non-parametric correlation and the laboratory changes and presence of positive cats was not interdependent. Identification of $E$. canis and $A$. platys revealed the disease in the region of Campos dos Goytacazes/RJ. The presence of A. phagocytophilum is considered an important finding due to its zoonotic potential.
\end{abstract}

INDEX TERMS: Anaplasmataceae, ehrlichiosis, anaplasmosis, cats, clinical and laboratory findings, PCR, immunofluorescence indirect assay, Rio de Janeiro, parasitoses.

\footnotetext{
${ }^{1}$ Recebido em 22 de abril de 2017.

Aceito para publicação em 2 de junho de 2017.

${ }^{2}$ Laboratório de Clínica e Cirurgia Animal, Hospital Veterinário, Universidade Estadual do Norte Fluminense Darcy Ribeiro (UENF), Avenida Alberto Lamego 2000, Parque Califórnia, Campos dos Goytacazes, RJ 28013-602, Brasil. *Autor para correspondência: andersonbtvet@gmail.com

${ }^{3}$ Laboratório de Patologia Clínica Veterinária, Faculdade de Agronomia e Medicina Veterinária, Universidade de Brasília (UNB), SGAN 605, Avenida L2 Norte, Brasília, DF 70910-900, Brasil.

${ }^{4}$ Laboratório de Referência Nacional em Vetores das Riquetsioses (SVS/MS) e de Referência Estadual em Ácari (SES/RJ), Instituto Oswaldo Cruz/Fiocruz, Avenida Brasil 4365, Manguinhos, Rio de Janeiro, RJ 21045-900, Brasil.
}

RESUMO.- No Brasil, até o ano 2000, os agentes riquetsiais em felinos domésticos eram poucos conhecidos, existindo somente relatos esporádicos de Ehrlichia sp. As recentes pesquisas envolvendo biologia molecular e agentes riquetsiais confirmam a ideia de que estes agentes estão presentes nesses animais e, por este motivo, demonstram a necessidade de estudos mais detalhados no Brasil. 0 objetivo do presente trabalho foi a caracterização dos agentes da família Anaplasmataceae que acometem os felinos domésticos e esclarecer a importância dos felinos na cadeia epidemiológica das doenças riquetsiais por 
métodos moleculares e sorológicos associando a presença das doenças aos parâmetros clínicos e laboratoriais. Foram obtidas amostras sanguíneas de 60 felinos domésticos, independentes de sanidade, provenientes de atendimentos clínicos. Destas amostras foram realizados hemograma e bioquímica sérica, e os dados foram utilizados para preenchimento da ficha laboratorial. As amostras foram processadas para obtenção de concentração de células e soro, para realização da reação em cadeia pela polimerase (PCR) e reação por imunofluorescência indireta (RIFI), respectivamente, para identificação de agentes da família Anaplasmataceae. Os dados foram utilizados para análise descritiva para formação de frequências epidemiológicas e para realização de testes não-paramétricos pelo Qui-quadrado de Pearson ( $\mathrm{p} \leq 5 \%$ ) associando as alterações laboratoriais às infecções por Ehrlichia canis, Anaplasma platys e Anaplasma phagocytophilum. Os resultados obtidos revelaram a presença de $33,33 \%$ de agentes Anaplamastaceae na amostra populacional, sendo $8,33 \%$ para E. canis, $20 \%$ para A. platys e $10 \%$ para A. phagocytophilum. Foram realizadas as sorologias das amostras, pela imunofluorescência indireta, para verificação de amostras reagentes para A. phagocytophilum, sendo 8,33\% amostras reagentes na amostra populacional. As alterações clínicas e laboratoriais mais frequentes em pacientes positivos por agentes Anaplasmataceae foram letargia, linfadenomegalia, mucosas pálidas, desidratação, trombocitopenia, hiperglobulinemia e hipoalbuminemia. Destes dados foram realizadas as correlações não paramétricas e não foram verificadas dependências das alterações laboratoriais com a presença de animais positivos para agentes Anaplasmataceae. A identificação dos agentes E. canis e A. platys visa esclarecer a doença na região, sendo instrumento de orientação da doença pelo médico veterinário ao proprietário para que tenha medidas adequadas de tratamento e prevenção. A presença de agentes $A$. phagocytophilum é considerada, sem dúvidas, uma notificação importante devido ao potencial zoonótico.

TERMOS DE INDEXAÇÃO: Anaplasmataceae, erliquiose, anaplasmose, felinos, alterações clínicas e laboratoriais, PCR, imunofluorescência indireta, Rio de Janeiro, parasitoses.

\section{INTRODUÇ̃̃o}

Desde que a ehrlichiose canina foi descrita pela primeira vez em 1935, e reconhecida nos Estados Unidos em 1962, houve muitos avanços importantes para a compreensão da diversidade dos organismos riquetsiais responsáveis pela ehrlichiose e anaplasmose em cães e, ocasionalmente, em gatos, dos vetores capazes de transmitir esses agentes, bem como importantes papéis destes serem patógenos veterinários e considerados agentes de doenças zoonóticas (Little 2010).

A população atual de gatos no Brasil em 2013 foi aproximadamente 22 milhões (IBGE 2015). A tendência é que este número continue crescendo, já que o gato é o animal doméstico que mais se ajusta ao estilo de vida do homem atual (Oliveira 2008). 0 conhecimento das doenças transmitidas por carrapatos em felinos é substancialmente menor comparado ao conhecimento das doenças transmitidas em pacientes caninos e humanos (Stubbs et al. 2000, Breitschwerdt et al. 2002). Os poucos relatos sobre a prevalência da ehrlichiose e anaplasmose felina em várias regiões do mundo podem ser devido à falta ou negligência de diagnósticos fidedignos para suas confirmações (Breitschwerdt et al. 2002, Lappin et al. 2004, Zobba et al. 2015).

0 raro diagnóstico da ehrlichiose e anaplasmose felina pode estar relacionado a vários fatores, incluindo: a escassez de conhecimento de doenças transmitidas por carrapatos nesta espécie, patogenicidade reduzida dos agentes transmitidos comparados a outros animais, ou remoção rápida dos carrapatos nos felinos, resultando na diminuição da oportunidade de transmissão da doença (Stubbs et al. 2000).

Nos últimos anos houve um avanço no entendimento das infecções transmitidas por carrapatos devido à aplicação de técnicas moleculares, em particular a Reação em Cadeia da Polimerase (PCR), utilizadas no diagnóstico e identificação desses agentes. As recentes pesquisas envolvendo biologia molecular e agentes riquetsiais confirmam a ideia de que estes agentes estão presentes nesses felinos e, por este motivo, demonstram a necessidade de estudos mais detalhados no Brasil (Lima et al. 2010).

Apesar da escassez de conhecimento sobre hemoparasitos, da falta de relatos e de realização do diagnóstico, a infecção em gatos por Ehrlichia spp. e Anaplasma spp. no Brasil, estes agentes estão presentes como potenciais parasitas e devem receber mais atenção por parte dos médicos veterinários e, mais ainda, pelos pesquisadores (Santarém et al. 2005, Lima et al. 2010).

O presente trabalho é de suma importância para caracterização das espécies que causam anaplasmose e ehrlichiose felina e para demonstrar a participação dos felinos domésticos na cadeia epidemiológica destas doenças, determinando as frequências de agentes na população de felinos e as características clínico-patológicas das infecções que acometem os felinos domésticos, por métodos moleculares e sorológicos associando a presença destes aos parâmetros clínicos e laboratoriais.

\section{MATERIAL E MÉTODOS}

Amostras. 0 projeto foi aceito pela Comissão de Ética de Uso de Animais (CEUA) da Universidade Estadual do Norte Fluminense Darcy Ribeiro sob o protocolo de n으559687. Foram obtidas amostras sanguíneas de 60 felinos domésticos provenientes de atendimentos no Hospital Veterinário da UENF, atendimentos particulares e gatis no município de Campos dos Goytacazes, RJ. Foram colhidas amostras sanguíneas independentemente da existência de sintomatologia clínica compatível com hemoparasitoses.

Aquisição das amostras sanguíneas. As amostras sanguíneas foram obtidas de todos felinos atendidos, os quais passaram por uma investigação para definir as sintomatologias e para, posteriormente, a formação dos dados estatísticos das principais alterações clínicas e laboratoriais dos animais positivos considerados doentes.

Avaliação de hemoparasitas em microscopia óptica. Foram confeccionados esfregaços sanguíneos a partir de sangue periférico obtido da borda de orelha de cada animal, coletado por punção auricular interna, aproveitando apenas a primeira gota de sangue. Estes foram corados com o kit Instant Prov (panótico rápido) da marca Newprov ${ }^{\circledR}$, sendo utilizado como uma das técnicas de Romanowsky, e posteriormente visualizados a microscopia óptica com objetiva de imersão em aumento de 100x em microscópio Nikon $^{\circledR}$, à procura de corpúsculos elementares (iniciais ou mórulas) em leucócitos e plaquetas, com o propósito de identificar agentes da família Anaplasmataceae na amostra. 
Realização de hemograma e testes bioquímicos. As amostras sanguíneas foram coletadas dos felinos no ato do atendimento, e devidamente acondicionadas foram transportadas para o setor de Patologia Clínica para avaliação hematológica e bioquímica sérica. Para cada animal, foi realizada a contenção física e a coleta realizada por flebocentese cefálica utilizando seringas de $5 \mathrm{~mL}$ e scalp 21' e a amostra sanguínea $(2,0-4,0 \mathrm{ml})$, onde parte foi armazenada em tubos contendo Etileno Diaminotetracético Tripotássico (EDTA $\mathrm{K}_{3}$ ). As amostras sanguíneas foram transportadas em frasco (Vacuette ${ }^{\circledR}$ ) e armazenadas a $4^{\circ} \mathrm{C}$, sendo enviadas no tempo máximo de 20 minutos para a realização do exame hematológico em equipamento automatizado da marca Labtest ${ }^{\circledR}$, SDH-20.

Realização dos ensaios imunológicos. Foi realizada a Reação por imunofluorescência indireta (RIFI). A presença de amostras reagentes para Anaplasma phagocytophilum foi de suma importância para determinação deste agente e, posteriormente, confrontado com as análises moleculares para validação de sua acurácia. No entanto, a possibilidade de reação cruzada não pôde ser descartada, pois a presença deste agente pode ocasionar na reação cruzada principalmente com Anaplasma platys e com Ehrlichia canis, apesar de alguns autores descreverem a imunofluorescência indireta ser considerado um ensaio específico (Waner et al. 2001, Lappin et al. 2004, Billeter et al. 2007). Desta forma, e como critério de avaliação, as amostras de todos felinos, inclusive as que foram reagentes para A. phagocytophilum, foram também aplicadas para investigação molecular para os agentes A. phagocytophilum, E. canis e A. platys, para verificar quais agentes que tiveram capacidade de formar reação para este ensaio imunológico para A. phagocytophilum, comprovando, ou não, a reação cruzada (Inokuma et al. 2002). 0 teste de Imunofluorescência indireta se baseou na detecção indireta de anticorpos IgG, sendo considerada uma análise semiquantitativa dos anticorpos da classe IgG felina para A. phagocytophilum, realizado sob vários graus de diluições para obtenção de titulações de reações. As análises foram realizadas em todos soros coletados de um número amostral de 60 gatos, seguindo as recomendações de uso pelo fabricante para o procedimento. Foi utilizado Kit de Imunofluorescência Indireta (RIFI) para A. phagocytophilum/Anticorpos IgG conjugado felino da marca Fuller Laboratories ${ }^{\circledR}$. Lembrando que em cada poço da lâmina contém células cultivadas com uma quantidade de agentes da espécie A. phagocytophilum capazes de promoverem reação com os anticorpos dos soros amostrais.

Extração do DNA do sangue total. O processo de extração do DNA do concentrado de células sanguíneas utilizando o kit comercial de extração da marca Ilustra blood genomicPrep Mini Spin Kit - GE Healthcare $^{\circledR}$.

PCR do GAPDH: avaliação da qualidade da extração do DNA. Após as extrações, as mesmas foram submetidas a uma PCR para testar a qualidade da extração do DNA e reduzir a quantidade de falsos negativos devido à presença de inibidores da PCR. Para isto foram utilizados os oligonucleotídeos GAPDH-F (5'-CCT TCA TTG ACC TCA ACT ACA T-3') e GAPDH-R (5'-CCA AAG TTG TCA TGG ATGACC-3'), sequências encontradas em todos os mamíferos, e que anelam em uma sequência específica do gene da enzima gliceraldeído 3 -fosfato desidrogenase e resulta em um produto amplificado de 400pb (Birkenheuer et al. 2003).

PCR dos agentes da família Anaplasmataceae. Os oligonucleotídeos, ou primers, utilizados para realização da PCR convencional para identificação do agente Ehrlichia canis foram propostos por Murphy et al. (1998). Os primers são pertencentes ao gene $16 \mathrm{~S}$ rRNA, sendo o ECAN-5 o primer Foward (5'-CAA TTA TTT ATA GCC TCT GGC TAT AGG A-3') e o HE3 o primer Reverse (5'-T+3'). 0 produto final amplificado ficou em torno de 398 pares de base (pb). Os oligonucleotídeos, ou primers, utilizados para identificação do agente Anaplasma platys foram propostos por Martin et al. (2005). Foram utilizados 4 tipos de primers, pois foram realizadas duas etapas da PCR, sendo considerada Nested PCR. Na primeira etapa foram usados oligonucleotídeos que amplificam grande parte do gene $16 \mathrm{~S}$ rRNA, sendo os primers 8 Foward (5' AGT TTG ATC ATG GCT CAG 3') e 1448 Reverse (5' CCA TGG CGT GAC GGG CAG TGT G 3'). Na segunda etapa da PCR foram utilizados o oligonucleotídeo PLATYS Foward (5' GAT TTT TGT CGT AGC TTG CTA TG 3') e outro oligonuclotídeo específico para o gênero Ehrlichia sp. EHR16S Reverse (5'TAG CAC TCA TCG TTT ACA GC 3') que produz um produto de amplificação de 678 pares de base (pb). Para identificação do Anaplasma phagpcytophilum pela PCR convencional, foram utilizados os primers MSP3 Foward e MSP3 Reverse, que são considerados fragmentos menores da sequência MSP2, pertencentes ao gene p44. Estes primers utilizados foram propostos por Zeidner et al. (2000) são mais específicos e formam produtos de amplificação de 334 pares de base (pb). 0 proposto par de primers é universal e muito eficiente, independentemente do tipo de amostra (por exemplo, sangue animal ou carrapatos) utilizado para amplificação do DNA das amostras de qualquer região geográfica (Zeidner et al. 2000). 0 oligonucleotídeo MSP3 Foward possui a sequência 5'-CCAGCGTTTAGCAAGATAAGAG-3' e o oligonucleotídeo MSP3 Reverse possui a sequência 5'- GCCCAGTAACATCATAAGC-3'. Após prontas as misturas, os preparos foram colocados no termociclador C1000 Thermocycler Biorad ${ }^{\circledR}$ para formação das reações para PCR, seguindo os ciclos necessários para desnaturação, anelamento e sequenciamento para amplificação de possíveis materiais genéticos dos agentes estudados.

Preparo do gel de agarose e corrida em eletroforese. Esta foi realizada após a possível amplificação do DNA, após o uso do termociclador, tendo como objetivo analisar, através de bandas a visualização macroscópica direta, as possíveis formações dos produtos estudados, ou seja, o DNA amplificado do agente estudado. Para averiguação primeiramente foi realizado o preparo do Gel de Agarose a $2 \%$ e corrida em eletroforese.

Análise dos dados. Foi realizada a análise descritiva dos dados através da obtenção de percentagens para determinar a proporção de amostras de animais positivos para os agentes estudados, seja nas avaliações dos esfregaços sanguíneos, nas amostras reagentes para $A$. phagocytiphilum nos ensaios imunológicos pela Imunufluorescência e positivos para as espécies de Ehrlichia spp. e Anaplasma spp. nas reações pelo PCR convencional das amostras sanguíneas coletadas dos pacientes felinos. A descrição dos resultados permitiu a realização do estudo epidemiológico e obtenção das proporções clínico-patológicas para verificação das frequências dos agentes da família Anaplasmataceae estudados e suas respectivas alterações clínico-laboratoriais em felinos domésticos no município de Campos dos Goytacazes, Rio de Janeiro. As análises descritivas realizadas estão descritas abaixo. Foi utilizada a estatística descritiva pela análise quantitativa proporcional, para formação dos dados epidemiológicos. Os cálculos de probabilidade foram baseados no espaço amostral $(\Omega)$ de 60 amostras de felinos domésticos na região de Campos dos Goytacazes, RJ. Foram utilizados apenas os dados dos animais postivos para algum agente Anaplasmataceae na PCR, sendo realizada estatística descritiva por análise quantitativa proporcional para obtenção das alterações laboratoriais em animais com alguma determinada infecção para agentes da família Anaplasmataceae. Com a finalidade de encontrar associações entre as alterações laboratorias e a presença de infecção (amostras positivas na PCR para agentes Anaplasmataceae) foi realizado o teste não-paramétrico Qui-quadrado 
de Pearson $(\mathrm{p} \leq 5 \%)$ por independência para demonstrar se os graus dos parâmetros (variável $\mathrm{y}_{\mathrm{i}}$ ), como parâmetro normal, parâmetro do grau de lesão inicial e parâmetro do grau de lesão avançado, ocorrem de forma independente ou dependente dos animais negativos assintomáticos (controle), suspeitos negativos e suspeitos positivos para agentes Anaplasmataceae (variável presença de agente $\mathrm{x}_{\mathrm{i}}$ ).

\section{RESULTADOS E DISCUSSÃO}

\section{Proporção de corpúsculos de inclusão (n e \%)}

Inicialmente os dados epidemiológicos foram distribuídos através das avaliações rotineiras laboratoriais na avaliação hematoscópica de formas compatíveis com corpúsculos de inclusão. Os corpúsculos de inclusão são formas reprodutivas dos agentes Anaplasmataceae em células sanguíneas ou em plaquetas (Dumler et al. 2001, Tarello 2005, Zobba et al. 2015). Considerado por muitos um teste de baixa sensibilidade, por ser de difícil identificação visual por microscopia óptica, e especificidade devido a outras formas que poderiam ocasionar uma falsa positividade de algum agente Anaplasmataceae, muitas das vezes são confundidos com artefatos na hematoscopia (Little 2010).

Primeiramente, foi analisada descritivamente a proporção de amostras positivas por corpúsculos de inclusão na avaliação hematoscópica do esfregaço sanguíneo. Foram encontradas 18 amostras de animais (30\%), de 60 animais, com a presença de corpúsculo de inclusão. Dados semelhantes podem ser visualizados em outro trabalho no nordeste dos Estados Unidos, no qual encontram proporção de 19\% dos animais em que foram realizados hematoscopia (Savidge et al. 2015). Foi verificado que, das 60 amostras dos felinos, 17 amostras $(28,3 \%)$ possuíram corpúsculos de inclusão em plaquetas, 3 amostras (5\%) possuíram corpúsculos de inclusão em neutrófilos e nenhuma amostra em monócitos. Na Figura 1 podem ser visualizados os corpúsculos de inclusão durante a pesquisa de hemoparasitas pela microscopia óptica.
A presença de corpúsculos de inclusão em células específicas pode ser de grande relevância quando há suspeita de algum determinado agente Anaplasmataceae. Dependendo do agente em questão, este pode possuir um tropismo maior para um determinado tipo celular (Dumler et al. 2001, Zobba et al. 2015). No entanto, este tipo de diagnóstico é relativo, pois o agente pode parasitar diferentes tipos celulares. Por esta razão foram verificadas a proporções de corpúsculo de inclusão para cada célula, como verificadas na Figura 2.

Em relação aos corpúsculos de inclusão em neutrófilos, um trabalho semelhante realizado na Itália por Tarello (2005) relata a presença de corpúsculos de inclusão em neutrófilos em $6 \%$ dos animais. Uma frequência maior de corpúsculos de inclusão em neutrófilos pode ser vista no trabalho realizado por Savidge et al. (2015) que encontraram em 19\% dos felinos no nordeste dos Estados Unidos. Um trabalho realizado em mesma cidade, através de Correa et al. (2011), revelou que 9,89\% apresentaram mórulas em plaquetas, diferentemente do atual trabalho. Infelizmente, muitos trabalhos relatam que corpúsculos de inclusão em monócitos são difíceis de serem encontrados nos animais infectados, em qualquer espécie animal, principalmente animais com Ehrlichia canis, mesmo na forma grave da doença (Harrus \& Waner 2011). Entretanto, em outros relatos corpúsculos semelhantes a formas de reprodução de Ehrlichia ou mórulas têm sido detectados em monócitos e linfócitos em gatos infectados naturalmente nos Estados Unidos, Quênia, França, Brasil e na Tailândia (Lappin \& Breitschwerdt 2012).

\section{Proporção de amostras positivas a PCR para agentes Anaplasmataceae}

Inicialmente os dados foram distribuídos para determinação da proporção de amostras positivas para agentes da família Anaplasmataceae pela PCR, ou seja, ambas Ehrlichia spp. e Anaplasma spp., e foi verificado que 20 gatos (33,3\%) das amostras de animais possuíam positividade para pelo menos algum agente da família. Frequências altas também
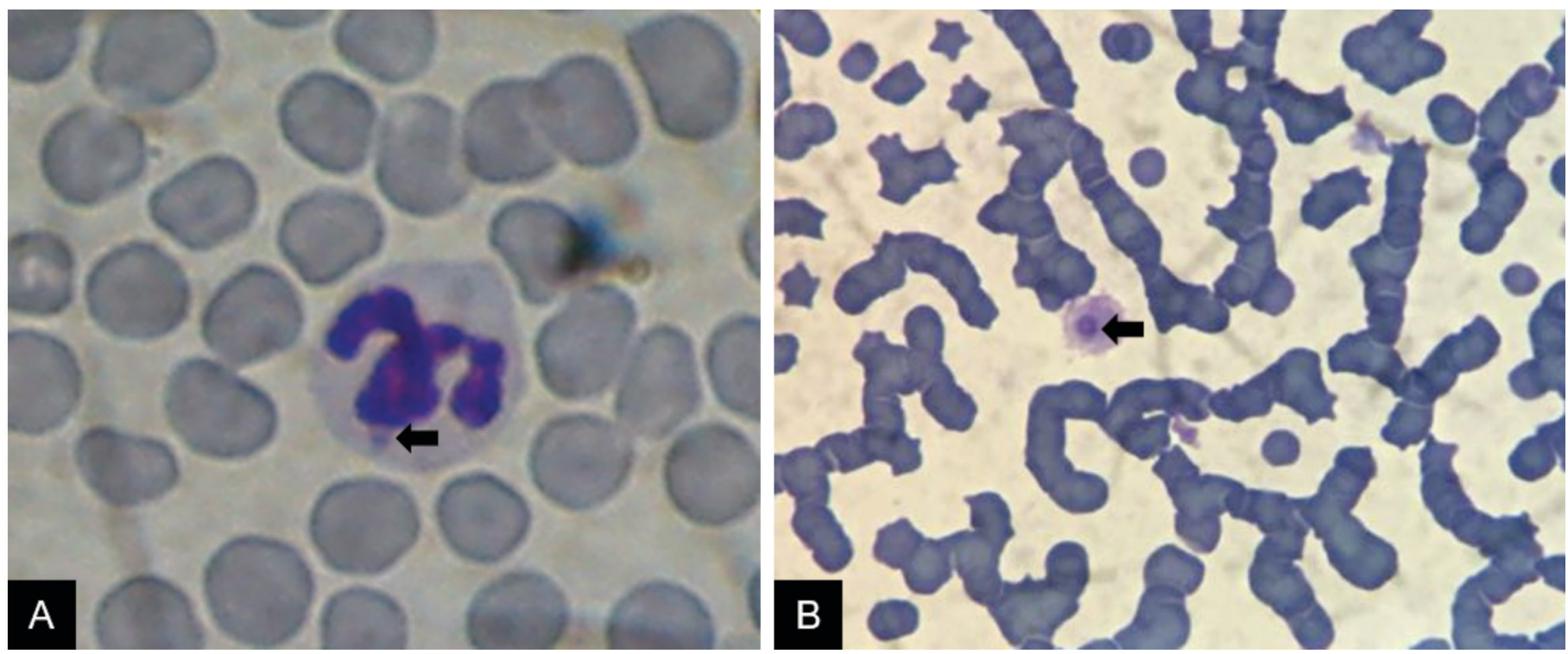

Fig.1. (A) Corpúsculo de inclusão em neutrófilo (seta) em pesquisa de hemoparasitas. Panótico, obj.100x. (B) Corpúsculo de inclusão em plaqueta (seta) em pesquisa de hemoparasitas. Panótico, obj.100x. 
PROPORÇÃo DE CORPÚSUCLOS DE INCLUSÃo EM CADA CÉLULA

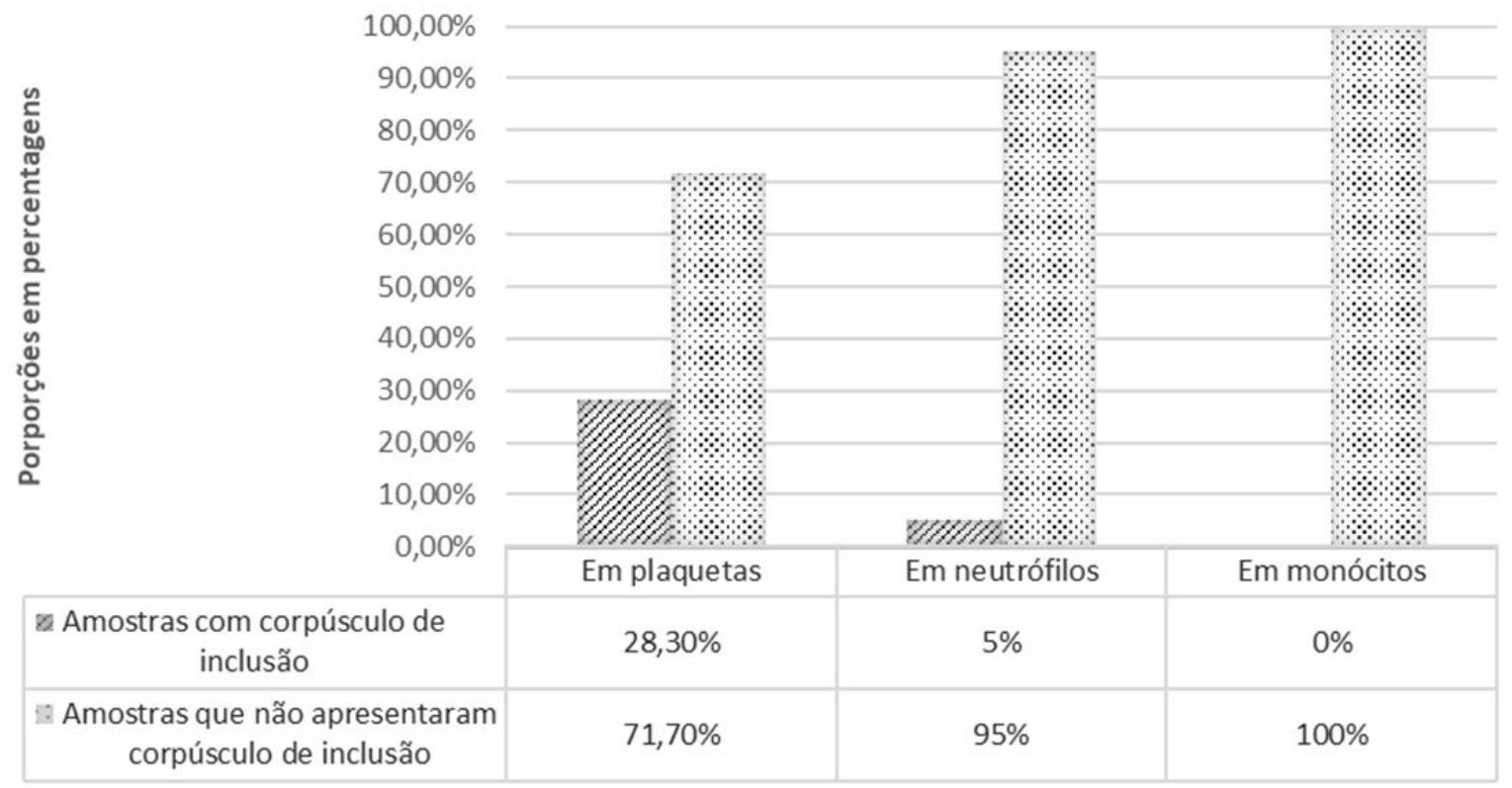

Fig.2. Proporção de corpúsculos de inclusão em cada célula dentro de uma amostra populacional (n=60) no município de Campos dos Goytacazes, RJ.

podem ser verificadas em vários trabalhos, como o trabalho relatado por Spada et al. (2014), em um trabalho realizado no norte da Itália, na qual encontraram uma alta frequência de $48,9 \%$. Foi encontrada uma alta frequência no trabalho elaborado por Aguirre et al. (2004) na região central da Espanha, sendo uma taxa de $17,9 \%$ de agentes. No trabalho realizado por Sasaki et al. (2012) no Japão foi encontrado uma proporção de $11,1 \%$ de amostras de felinos positivos para Anaplasmataceae. Frequências menores em amostras positivas para Anaplasmataceae podem ser verificadas em outros trabalhos. 0 trabalho realizado por Maia et al. (2014) no Sul de Portugal verificou uma frequência de $5,4 \%$, uma frequência bem similar do trabalho realizado por Hegarty et al. (2015) que foi de 3,2\%, trabalho este realizado no laboratório de diagnósticos de doenças transmitidas por vetores da Faculdade de Medicina Veterinária da Universidade da Carolina do Norte, sendo amostras submetidas de vários locais dos Estados Unidos. No sul da Alemanha também foi realizado um trabalho por Bergmann et al. (2015) que encontraram uma frequência de apenas $0,4 \%$, sendo baixa comparada ao atual trabalho. Um trabalho realizado por André et al. (2015) na região Centro-oeste do Brasil, na cidade de Campo Grande do estado de Mato Grosso do Sul, foi encontrado uma frequência de 8,5\% apenas. Vale ressaltar que apenas foi encontrado o gênero Ehrlichia, não sendo encontradas espécies do gênero Anaplasma, sendo assim o gênero Ehrlichia representou a família Anaplasmataceae neste trabalho de Mato Grosso do Sul.

\section{Proporção de amostras positivas ao PCR para Ehrlichia canis}

A proporção de amostras positivas para o agente $E$. canis foi de 5 gatos (8,33\%), das 60 amostras de animais. Resultado muito semelhante pode ser verificado no trabalho de Braga et al. (2014), na cidade de Cuiabá, Mato Grasso, no Brasil, em que foi verificada uma frequência de $9,4 \%$ de amostras positivas para este agente. Frequências menores podem ser verificadas em alguns trabalhos. Em um trabalho realizado no Brasil, na cidade de São Luís, no Maranhão, foi verificada uma proporção de 0,5\% de amostras infectadas por este agente (Braga et al. 2012). Uma pequena frequência pode ser vista também no trabalho e André et al. (2015), na cidade de Campo Grande, estado de Mato Grosso do Sul, Brasil, sendo uma proporção de 0,66\%. Frequências maiores na população de felinos, identificadas através da realização da PCR para E. canis, também podem ser encontradas, como o trabalho realizado por Oliveira et al. (2009), na cidade de Viçosa, estado de Minas Gerais, Brasil em que foi encontrada uma proporção de $20 \%$ de animais positivos para este agente. Outra alta frequência encontrada foi no trabalho elaborado por Aguirre et al. (2004) na região central da Espanha, em que encontraram uma proporção de $17,9 \%$ de amostras positivas. É interessante relatar que a baixa percentagem de animais positivos para este agente, como vista no presente estudo, da mesma forma como em outros trabalhos, é explicada possivelmente pelo fato de que os felinos domésticos são mais resistentes as infecções promovidas pelo agente E. canis quando comparados aos cães, pois a interação entre estes animais e o mesmo vetor, no caso o carrapato, é diferente. Obviamente que isso se refere ao comportamento do gato em remover os carrapatos, e isso possibilita a redução da taxa de inoculação do agente pelo vetor (Kidd \& Breitschwerdt 2003). Por isso que muitos trabalhos revelam que é incomum a infecção por E. canis nos felinos (Braga et al. 2012).

Proporção de amostras positivas a PCR para Anaplasma platys A proporção de amostras positivas para o agente Anaplasma platys foi de 12 gatos (20\%), das 60 amostras de animais. Um trabalho realizado por Zobba et al. (2015) no Hospital Acadêmico Veterinário, identificou 31,11\% de felinos positivos para A. platys, uma frequência considerada elevada 
comparada ao presente estudo. No trabalho realizado por Correa et al. (2011) em Campos dos Goytacazes assim como no atual trabalho, no estado do Rio de Janeiro, foi encontrada uma frequência de 13,19\%. Este trabalho foi o trabalho mais contundente em relação a Anaplasmose trombocitopênica felina, há muitos trabalhos encontrados em outras espécies, principalmente em cães na qual a parasitemia é muito maior do que em gatos (Inokuma et al. 2000, Alves et al. 2005, Doyle et al. 2005). Outro trabalho realizado no Brasil foi a identificação deste agente em um felino doméstico, do estado do Pernambuco, demonstrando que a identificação deste agente acontece raramente (Lima et al. 2010).

\section{Proporção de amostras positivas a PCR para Anaplasma phagocytophilum}

Como trabalho inédito no município de Campos dos Goytacazes, foi verificada a presença de animais infectados com A. phagocytophilum, agente este conhecido por causar a Anaplasmose granulocítica em animais, inclusive felinos, e humanos. Sendo de extrema relevância por ser considerada uma doença antropozoonótica (Dumler et al. 2007, Bakken \& Dumler 2008, Little 2010). Sendo assim, a proporção de amostras positivas para o agente $A$. phagocytophilum foi de 6 gatos (10\%), das 60 amostras de animais, sendo considerada uma alta frequência no município de Campos dos Goytacazes. Spada et al. (2014), em uma investigação no norte da Itália, encontraram uma alta frequência de $17,7 \%$ de amostras de felinos positivos para A. phagocytophilum. Entretanto, como relatado na maioria dos trabalhos, a frequência encontrada para o agente $A$. phagocytophilum é geralmente baixa em amostras populacionais de felinos. No trabalho elaborado por Savidge et al. (2015) foi encontrada uma frequência e 0,92\% de amostras positivas para este agente em felinos, trabalho este realizado no nordeste dos Estados Unidos. Da mesma forma pode ser verificado em um trabalho realizado no sul da Alemanha, por Bergmann et al. (2015), em que encontraram uma proporção de $0,42 \%$ de felinos positivos em PCR para este agente. Da mesma forma no trabalho realizado por Hegarty et al. (2015), na qual encontraram uma proporção de $2,45 \%$ de amostras positivas na qual foram submetidas a análise no laboratório de diagnósticos de doenças transmitidas por vetores da Faculdade de Medicina Veterinária da Universidade da Carolina do Norte, sendo amostras submetidas de vários locais dos Estados Unidos.

\section{Confrontando as amostras positivas em PCR para agentes} Anaplasmataceae com os dados de corpúsculos de inclusão

O diagnóstico de corpúsculos de inclusão pela investigação hematoscópica é impreciso, pela necessidade de ter um técnico laboratorial altamente treinado para a evidenciação destas formas na microscopia. Muitas das vezes, a notificação de algum agente Anaplasmataceae por este tipo de diagnóstico não ocorre de forma coerente no laboratório de rotina, sendo considerado um diagnóstico de baixa sensibilidade. Da mesma forma, pode-se pensar que muitos artefatos em microscopia durante o exame do esfregaço sanguíneo são capazes de promover um diagnóstico inadequado, sendo em algumas vezes confundidos com as formas compatíveis com corpúsculos de inclusão, e por esta razão também sendo considerado um teste com baixa especificidade (Dawson et al. 2005, Little 2010). Por esta razão foi necessário confrontar os dados dos animais comprovadamente infectados, ou seja, positivos para PCR, com os dados de corpúsculos de inclusão, assim como confrontar com a presença de corpúsculos de inclusão nas células específicas. Desta forma, verificando a sensibilidade e especificidade do diagnóstico hemotoscópico de corpúsculos de inclusão compatíveis com formas de agentes Anaplasmataceae.

Para tal investigação, inicialmente foram confrontados os dados das amostras positivas para Anaplasmataceae através da PCR dos felinos com os dados das amostras em que foram encontrados corpúsculos de inclusão. A hipótese principal foi verificar quantas amostras positivas na PCR tiveram a presença de corpúsculos de inclusão. No presente trabalho é demonstrado dentre os 20 gatos positivos para Anaplasmataceae na PCR, concomitantemente 3 gatos (15\%) apresentaram corpúsculos de inclusão. Tais dados demonstram, dentre as amostras comprovadamente infectadas na PCR, que poucas amostras foram evidenciadas corpúsculos de inclusão na hematoscopia, presumindo que o diagnóstico para avaliação dos corpúsculos de inclusão é de baixa sensibilidade, assim como corroborado por Little (2010), que explica que a maioria das mórulas não se apresenta em amostras de animais realmente infectados.

\section{Confrontando as amostras positivas em PCR para Anaplasma phagocytophilum com os dados de corpúsculos de inclusão em neutrófilos}

Foram avaliadas também, seguindo a mesma dissertativa, as proporções de amostras positivas na PCR para cada agente específico com a presença de corpúsculos de inclusão em suas respectivas células em que estes agentes parasitam e se reproduzem. Inicialmente foi avaliada a proporção de amostras positivas para A. phagocytophilum que possuíram corpúsculos de inclusão em neutrófilos, e foi verificada uma proporção de $16,67 \%$, pois de 6 amostras de animais positivos na PCR para este agente apenas 1 apresentou corpúsculo de inclusão em neutrófilo.

Savidge et al. (2015) explanam em sua pesquisa que apenas a presença de corpúsculos de inclusão em neutrófilos corroboram com a positividade do agente. Entretanto, no atual trabalho, com os resultados verificados quando se confronta a PCR para este agente (que confirma que a amostra está infectada) com este teste hematoscópico, verifica-se que houve uma pequena proporção do diagnóstico para ambos os testes confirmando que o teste hematoscópico é de baixa sensibilidade. No entanto, um trabalho realizado por Heikkilä et al. (2010), em um relato de caso de um atendimento de um felino no Hospital Veterinário da Universidade de Helsinki na Finlândia, o diagnóstico se deu através da visualização da mórula intracitoplasmática em neutrófilos. Em mesma pesquisa, posteriormente, foi realizada a PCR da amostra sanguínea para confirmação do agente $A$. phagocytophilum, e foi comprovado que a amostra, realmente, era positiva para este agente. Portanto, entende-se que apesar de ser um teste de baixa sensibilidade, quando encontrado formas compatíveis com corpúsculos de inclusão em neutrófilos, possivelmente estas amostras são positivas para este agente, mas para confirmar isso foi avaliado a especificidade entre os testes.

Posteriormente, foi verificada a especificidade da avaliação de corpúsculos de inclusão na hematoscopia e do teste de PCR. Foi verificado através do tropismo celular, com a presença de corpúsculo de inclusão em neutrófilos, o diagnóstico da infecção específica do A. phagocytophilum. Para isso foi verificado quantas 
amostras, que foram positivas para corpúsculo de inclusão em neutrófilos, foram positivas na PCR para A. phagocytophilum, já que a presença de corpúsculos ou mórulas em neutrófilo presume que a infecção seja causada por este agente como relatado por outros trabalhos que explicam que a identificação de mórulas em neutrófilo é considerada uma anormalidade específica do agente $A$. phagocytophilum, pois estes autores confirmaram na PCR a presença deste agente (Tarello 2005, Savidge et al. 2015). No presente estudo foi encontrado 3 amostras em que foram identificados corpúsculos de inclusão em neutrófilos, no entanto quando estas mesmas amostras foram colocadas a prova na PCR para confirmação do agente, apenas uma amostra foi positiva, concluindo que dois animais realmente não foram diagnosticados precisamente. Podendo ser justificado, pois a presença de corpúsculo de Döhle ou a presença de cromatina sexual em neutrófilos podem ser confundidos e devem ser cuidadosamente diferenciados de inclusões intracitoplasmáticas de mórulas ou corpúsculos do agente (Savidge et al. 2015).

\section{Confrontando as amostras positivas em PCR para Anaplasma platys com os dados de corpúsculos de inclusão em plaquetas}

Ao verificar a proporção de amostras positivas para A. platys que possuíram corpúsculos de inclusão em plaquetas, foi constatada proporção de 8,33\%, na qual das 12 amostras positivas na PCR para este agente apenas 1 apresentou corpúsculo de inclusão em plaquetas. De fato, muitas amostras positivas para este agente relatam a presença de corpúsculos de inclusões em plaquetas semelhantes a A. platys (Harvey 2012). Realmente dentre as amostras positivas confirmadas, apenas uma amostra foi identificada a inclusão em plaquetas sugere que a visualização da inclusão é difícil, sendo corroborado por Little (2010) quando explica que as mórulas de $A$. platys podem ser encontradas em plaquetas, mas, em alguns casos, a visualização pode ser dificultada pela indistinção de grânulos plaquetários. E possivelmente, por esta dificuldade e pela baixa sensibilidade, a confirmação deste agente torna-se prejudicada. É interessante relatar também que devido à natureza cíclica da doença, encontrar a inclusão no interior das plaquetas de animais doentes não é uma tarefa fácil, e na maioria das vezes é um achado acidental. Isso pode ser explicado pela diminuição da contagem de plaquetas durante a infecção e, consequentemente, diminuição do número de microrganismos circulantes. A baixa frequência de parasitas no esfregaço de sangue faz com que o método não seja tão preciso, especialmente durante a fase trombocitopênica (Correa et al. 2011).

Logo após foi verificado através do tropismo celular, com a presença de corpúsculo de inclusão em plaquetas, o diagnóstico da infecção específica do A. platys. Para isso, foi verificado quantas amostras, que foram positivas para corpúsculo de inclusão em plaquetas, foram positivas na PCR para A. platys. No presente trabalho, logo se verifica que foram encontradas 17 amostras positivas na visualização de corpúsculos de inclusão, e, destas, apenas uma amostra foi confirmada no PCR para este agente, configurando também um teste de baixa especificidade. Há uma grande dificuldade no diagnóstico de corpúsculos ou mórulas em plaquetas, pois estes fragmentos celulares geralmente possuem granulações semelhantes a estas formas, granulações formadas no citoplasma de megacariócitos antes da formação das plaquetas (Little 2010).

\section{Confrontando as amostras positivas em PCR para Ehrlichia canis com os dados de corpúsculos de inclusão em monócitos}

Quando foi verificado que dentre as amostras tinham aquelas positivas para E. canis pensava-se encontrar corpúsculos de inclusão na avaliação hematoscópica destas mesmas amostras sanguíneas em células em que frequentemente este agente parasita, devido ao seu tropismo, no caso os monócitos (Lappin \& Breitscwerdt 2012). No entanto, no presente estudo não foi evidenciado dentre as amostras positivas na PCR para E. canis a presença de corpúsculos de inclusão nestas células em microscopia.

\section{Confrontando as amostras positivas em PCR para Ehrlichia canis com os dados de corpúsculos de inclusão em plaquetas}

No entanto, sabendo que as plaquetas são capazes de albergar as formas reprodutivas deste agente (Zobba et al. 2015), foi verificado que dentre as amostras positivas na PCR para E. canis que $20 \%$, uma amostra de cinco positivas na PCR para este agente, apresentavam corpúsculos de inclusão em plaquetas. Como relatado por Mylonakis et al. (2003), as plaquetas podem ser parasitadas tanto por E. canis quanto por A. platys, e isso justifica a presença de corpúsculo de inclusão em plaquetas na amostra comprovadamente estar infectada por E. canis, como no presente estudo. Almosny (1998) ainda faz esta mesma afirmação, que mórulas de E. canis podem ser observadas em plaquetas, podendo ser confundida com A. platys baseando-se na identificação morfológica do agente na célula parasitada. D’Agnone (2006) observou a presença de E. canis em plaquetas de dois cães por meio da PCR, assim como Sousa (2006) que também observou mórulas de E. canis em plaquetas de dois cães. Semelhantemente, Ramos et al. (2009) através da PCR observaram que de quatro cães com mórulas em plaquetas, três eram E. canis e apenas uma amostra era A. platys.

Desta forma, também foi verificado através do tropismo celular, com a presença de corpúsculo de inclusão em plaquetas, o diagnóstico da infecção específica do E. canis. Para isso, foi verificado quantas amostras, que foram positivas para corpúsculo de inclusão em plaquetas, foram positivas na PCR para E. canis. Das 17 amostras em que foram encontrados corpúsculos de inclusão em plaquetas, uma amostra foi positiva na PCR para E. canis. Isso demonstra que é um teste de baixa especificidade para confirmação que as presenças de corpúsculos em plaquetas sejam de A. platys, já que E. canis pode parasitá-las, como relatado por Almosny (1998) e em alguns trabalhos (D'Agnone 2006, Ramos et al. 2009).

\section{Proporção de amostras reagentes a RIFI para Anaplasma phagocytophilum}

Para formação de dados epidemiológicos, as amostras reagentes pela RIFI para A. phagocytophilum foram distribuídas descritivamente para confecção das proporções deste agente. As amostras de plasma foram consideradas reagentes a partir da titulação 400 (diluição 1:400), considerado o "cut off" neste presente estudo. Foi encontrada uma proporção de 8,33\% de 
amostras reagentes ( 5 amostras), sendo considerado o grupo amostral que possuíram contato com o agente em questão.

Um trabalho realizado por Billeter et al. (2007) nos Estados unidos relata a presença de uma proporção de 4,3\% de amostras reativas em felinos, até mesmo uma proporção semelhante, no entanto estes relatam que em áreas endêmicas a proporção de amostras reagentes para este agente chegue aproximadamente 30\%. Esta mesma proporção é verificada no trabalho realizado por Magnarelli et al. (2005), que verificaram também a taxa de $30 \%$ de felinos reagentes para $A$. phagocytophilum no nordeste dos Estados Unidos. 0 resultado do presente trabalho foi muito semelhante ao trabalho realizado por Aguirre et al. (2004) na região central da Espanha que demonstra uma proporção de 4,9\% das amostras dos felinos reagentes. No entanto, um trabalho mais recente realizado por Ayllon et al. (2009), também na região central da Espanha, verificaram uma frequência de $7,7 \%$ de amostras de felinos que apresentam reação para A. phagocytophilum, sendo um valor muito próximo ao atual estudo. Ebani \& Bertelloni (2014), na região central da Itália, também verificaram uma proporção muito semelhante, com 4,5\% de amostras reagentes. No Brasil apenas um trabalho realizado por Yamanaka et al. (2014) em Cuiabá, Mato Grosso, demonstrou uma proporção de 7,77\% de felinos reagentes para este agente, sendo um valor próximo ao atual estudo.

\section{Confrontando as amostras reagentes na RIFI para Anaplasma phagocytophilum com amostras positivas em PCR para Anaplasma phagocytophilum}

Seguind o o mesmo critério, de verificar a especificidade do teste para o estudo epidemiológico, as amostras reagentes pela RIFI para A. phagocytophilum também foram confrontadas com amostras positivas para PCR para cada agente Anaplasmataceae estudado, a fim de verificar se a presença de infecção para outros agentes é capaz de formar amostras reagentes na RIFI, confirmando assim a reação cruzada. Sendo assim avaliando a especificidade do teste. Primeiramente foi investigado se as amostras que foram reagentes tiveram a presença do próprio agente, $A$. phagocytophilum, através da amplificação do ADN do agente pela PCR, ou seja, amostras realmente infectadas. Foi verificado que em 5 amostras reagentes, apenas 1 amostra foi positiva na PCR para A. phagocytophilum, uma proporção de $20 \%$ das amostras reagentes. Coincidentemente, nesta mesma amostra que também positiva na PCR, foi encontrado inclusão por mórula em neutrófilo, confirmando que esta mórula realmente era composta por A. phagocytophilum. Entretanto na maioria das amostras reagentes para este agente, não se pôde comprovar a riquetsemia. Os felinos possuem uma capacidade de formar anticorpos na fase aguda da doença promovida por este agente, desta forma pode-se identificar mórulas em neutrófilos pela hematoscopia, da mesma forma se pode amplificar o ADN do agente na PCR (Bjöersdorff et al. 1999), e que pode explicar a presença desta amostra reagente na RIFI que foi positiva em PCR. No entanto, isso não acontece normalmente, pois geralmente o tempo de soroconversão acontece na forma crônica da doença, como é relatado também em cão (Ebani \& Bertelloni 2014). Nesta fase a riquetsemia não está presente e não pode ser identificada tanto a nível microscópico quanto molecular (Little 2010). No presente estudo verificou-se que na maioria das amostras reagentes para este agente não houve a presença de riquetsemia, como verificado por estes autores.

Billeter et al. (2007) no trabalho realizado em felinos em várias regiões dos Estados Unidos, verificaram que em todas amostras de felinos que foram positivas na RIFI para A. phagocytophilum não houve amplicação em PCR, ou seja, estas mesmas amostras foram negativas. Aguirre et al. (2004), no trabalho realizado na Espanha, verificaram também que todas amostras reagentes para este agente não foram positivas na PCR. Lappin et al. (2004) elucidam que estes microorganismos evadem para outros tecidos, principalmente linfoides, e nesta condição estes agentes não estão presentes nas amostras sanguíneas. Este mesmo autor relata que há persistência de altos títulos de anticorpos mesmo em felinos doentes após a terapia específica, e que por esta circunstância eliminaram o agente, confirmados pela negatividade em análise pela PCR. Uma vez que este diagnóstico da RIFI na identificação do agente é impreciso, isso permite considerar que este teste possua uma baixa especificidade.

\section{Confrontando as amostras reagentes na RIFI para Anaplasma phagocytophilum com amostras positivas em PCR para Ehrlichia canis}

Foi verificado, a fim de comprovar a presença de reação cruzada, se dentre as amostras reagentes pela RIFI houve a presença de infecções por outros agentes. Assim, foi verificado que em 5 amostras reagentes, 1 amostra foi positiva na PCR para E. canis, ou seja 20\% das amostras reagentes. Alguns autores relatam a reação cruzada entre os dois agentes no ensaio de RIFI, embora a infecção em agente distinto ao que o teste preconiza possa gerar um título de anticorpo mais baixa do que o título sobre o agente primário (Waner et al. 2001, Little 2010). Por este motivo, pode-se entender a presença da reação cruzada para o agente E. canis na amostra de um felino, no presente estudo. Entretanto, tal reação enfatiza ainda mais o tema da baixa especificidade do teste, não sendo fidedigno para identificação do agente A. phagocytophilum, apesar da utilização de um "cut off" na titulação de 1:400 como nível limítrofe exigido para considerar a reação positiva, como citado nas instruções de uso do kit sorológico de RIFI.

Em contraste, muitos trabalhos relatam a inexistência de reação cruzada nos testes sorológicos entre A. phagocytophilum e E. canis, como o trabalho realizado por Solano-Gallego et al. (2006) na Espanha, na qual relatam que em todas amostras reagentes para $A$. phagocytophilum, os mesmos não tiveram a amplificação do ADN do agente E. canis. 0 mesmo pode ser relatado no estudo realizado por Billeter et al. (2007), nos Estados Unidos, que sugeriram que as 18 amostras reagentes para A. phagocytophilum poderiam ser consequência da reação cruzada para E. canis, no entanto não houve a confirmação deste agente na PCR.

\section{Confrontando as amostras reagentes na RIFI para Anaplasma phagocytophilum com amostras positivas em PCR para $A$. platys}

Como muitos autores relatam, geralmente, a presença do agente $A$. platys na amostra promove a reação cruzada na imunofluorescência indireta para $A$. phagocytophilum, pois os anticorpos IgG contra o agente $A$. platys pode se ligar aos antígenos de A. phagocytophilum na lâmina de imunofluorescência, gerando reação de fluorescência (Harvey 2012). De acordo com Heikkilä et al. (2010), eles explicam que estas reações 
cruzadas estão mais relacionadas com a presença do agente A. platys. No entanto, após a reclassificação dos gêneros por Dumler et al. (2001), estas evidências ficaram um pouco confusas. Contraposto a isso, no presente estudo não foi verificada a presença de amostras positivas de amostras positivas ao PCR A. platys dentre as amostras reagentes na RIFI para o agente $A$. phagocytophilum. 0 estudo realizado por Ferreira et al. (2008), realizado no Brasil, se assemelha ao atual estudo, cujo trabalho não foi observada reação cruzada no teste imunoenzimático na detecção de anticorpos contra A. phagocytophilum em amostras positivas na PCR para A. platys.

\section{Taxas de coinfecção}

Os dados obtidos para coinfecção na epidemiologia da região são mais apurados e fidedignos quando utilizados os dados moleculares, por serem considerados testes altamente sensíveis e específicos, pois comprovam a presença do agente estudado no indivíduo (Aguirre et al. 2004). Por esta razão, estes dados são os que melhores representam a epidemiologia no presente estudo. Portanto, estes dados moleculares são importantes para determinar e comprovar as taxas de coinfecção entre os agentes estudados. Logicamente que este estudo foi realizado formando as proporções retiradas da amostra populacional de 60 amostras dos felinos domésticos, gerando as taxas de coinfecção na amostra populacional, sendo considerado também um estudo epidemiológico.

A taxa de coinfecção encontrada de E. canis e A. phagocytophilm na amostra populacional foi de 1,67\%, ou seja, apenas 1 felino de 60 possuiu a infecção por estes dois agentes. Não há relatos de coinfecção entre estes dois agentes em felinos, já que o diagnóstico da infecção por A. phagocytophilum é complicado e requer inúmeras técnicas (Carrade et al. 2009), por esta razão são geradas poucas informações. No entanto, sendo muito importante este relato no presente estudo, sendo inédito na região. A primeira evidência da coinfecção entre os dois agentes foi relatada por Silveira et al. (2015), entretanto, sendo encontrado 1 animal positivo para ambos os agentes. Muitos trabalhos relatam reação cruzada ou presença de coinfecções através da análise sorológica, mas sem confirmações por testes mais específicos (Ebani \& Bertelloni 2014)

A taxa de infecção encontrada de A. platys e A. phagocytophilum foi de 3,33\%, sendo 2 gatos da amostra populacional. Não há relatos em literatura sobre tais coinfecções, necessitando de mais estudos sobre estes casos no presente trabalho. Sabe-se que muitos trabalhos correlacionados são de reação cruzada nos testes sorológicos como relatado em vários trabalhos (Heikkilä et al. 2010, Harvey 2012), mas não sobre coinfecção entre estes dois agentes.

Não foi encontrada taxa de coinfecção em E. canis e A. platys no presente trabalho. Vários trabalhos têm demonstrado coinfecções entre estes dois agentes (Little 2010). A infecção causada apenas por $A$. platys é relativamente baixa, por outro lado a coinfecção com $E$. canis tem demonstrado elevadas alterações clínicas e laboratoriais em pacientes, principalmente no cão (Gaunt et al. 2010).

\section{Alterações clínicas em animais positivos para agentes Anaplasmataceae}

Os dados discutidos até o momento foram epidemiológicos, no entanto o presente trabalho também contém alguns pontos principais que são as alterações clínicas e laboratoriais promovidas pelas infecções nos felinos. Estes dados foram adquiridos através das fichas clínicas e dos dados laboratoriais hematológicos e bioquímicos séricos, lembrando que os gatos passaram por atendimentos clínicos, independentemente de suas condições de sanidade, onde foi realizado o preenchimento da ficha clínica, devidamente padronizado para todos os animais, e a coleta de amostras sanguíneas para a realização do hemograma, incluindo a pesquisa de hemopasitoses, e a realização das bioquímicas séricas para a avaliação das funções hepática e renal. Estes dados foram considerados clínico-patológicos. Os dados foram distribuídos para a formação descritiva de frequências das alterações clínicas e laboratoriais, sendo escolhidas as alterações dos animais que foram positivos na PCR para os agentes, que por sua vez continham a infecção.

Apesar da descrição de alterações compatíveis com a ehrlichiose e anaplasmose, estas mesmas não são bem entendidas em felinos, devido à inespecificidade destas alterações, além do surgimento ser raro quando comparados aos cães (Stubbs et al. 2000). Sabe-se que os felinos domésticos são susceptíveis a infecções experimentais por A. phagocytophilum, nas quais há alguns relatos, mas tentativas de infecções experimentais com E. canis não têm sido relatadas, sendo escassas as informações de alterações compatíveis com a doença em tal infecção (Little 2010). No entanto, pouco se sabe sobre as infecções naturais nos felinos domésticos.

Primeiramente, foram verificadas as frequências de alterações clínicas dos felinos positivos a PCR para qualquer agente Anaplasmataceae, sendo dentre os 20 felinos que foram positivos para os agentes desta família. As alterações clínicas que mais se destacam dentre estes felinos foram a linfadenomegalia (25\%), presença de vetores (25\%), neste caso as pulgas, letargia (15\%), mucosas pálidas (15\%). Já outras alterações que foram encontradas foram perda de peso (5\%), edema (5\%), dificuldade de locomoção (5\%), êmese (5\%), afecção ocular (5\%) e desidratação (5\%). A ocorrência de infecções naturais por Ehrlichia spp. e Anaplasma spp. (principais representantes da família Anaplasmataceae em felinos) têm sido documentados nos gatos, e as apresentações clínicas descritas mais comuns foram febre, letargia e anorexia (Bouloy et al. 1994, Breitschwerdt et al. 2002, Lappin et al. 2004).

Os sinais predominantes reportados em gatos com ehrlichiose incluem a febre, letargia, mialgia, dispneia e linfadenomegalia (Stubbs et al. 2000). Alterações na locomoção e poliartrites também têm sido reportadas (Stubbs et al. 2000, Breitschwerdt et al. 2002). Sinais similares têm aparecido em felinos com infecções por A. phagocytophilum, incluindo dor nas articulações e dificuldade de locomoção, linfadenomegalia, perda de peso, assim como outras alterações como doenças periodontais, conjuntivites e sinais neurológicos (Bouloy et al. 1994, Stubbs et al. 2000, Breitschwerdt et al. 2002, Lappin et al. 2004, Tarello 2005, Little 2010). Como verificado, os sinais e sintomas que mais representam as alterações promovidas em ambos os gêneros são dificuldade de locomoção e linfadenomegalia, sendo também encontrado no atual estudo. No entanto, foi encontrado várias outras alterações e estas serão melhor detalhadas sendo explicada em cada agente especificamente. As frequências destas alterações em gatos infectados por agentes Anaplasmataceae do presente estudo podem ser verificadas na Figura 3. 


\section{Alterações laboratoriais em animais positivos para agentes Anaplasmataceae}

Da mesma maneira, foram verificadas as frequências de alterações laboratoriais dos felinos positivos na PCR para os agentes da família Anaplasmataceae do presente estudo. Os achados mais comuns descritos pelos autores de felinos com a presença de agentes Anaplasmataceae são anemia, leucocitose, leucopenia, linfocitose, neutrofilia, Desvio nuclear neutrofílico à esquerda, monocitose, linfocitopenia, trombocitopenia, hiperproteinemia, hiperglobulinemia, hipoalbuminemia, alterações renais (pelos níveis de uréia e creatinina sérica) e alteração hepática (aumento de alanina aminotransferase) (Aguirre et al. 2004, Ortuño et al. 2005, Little 2010, Bergmann et al. 2015, Hergarty et al. 2015).

Inicialmente, foram verificadas as alterações laboratoriais mais frequentes dentro dos 20 animais positivos para algum agente da referida família. Notadamente estas alterações foram muito semelhantes as descritas pela literatura, como descrito anteriormente. As alterações foram trombocitopenia
(35\%), hiperproteinemia (35\%), hiperglobulinemia (55\%) e hipoalbuminemia (35\%). As demais alterações foram neutrofilia (15\%), Desvio nuclear de neutrófilos à esquerda leve (DNNE leve - 15\%), linfocitopenia (10\%), linfocitose (15\%), monocitose (10\%), aumento de alanina aminotransferase sérica (ALT - 10\%), aumento de uréia sérica (5\%) e aumento de creatinina sérica (5\%). Estas alterações serão melhores descritas quando verificados em cada agente da família. Estas alterações podem ser verificadas na Figura 4.

\section{Correlações entre as alterações laboratoriais e felinos infectados com agentes Anaplasmataceae}

As principais alterações laboratoriais encontradas nos felinos domésticos positivos para os agentes da Anaplasmataceae foram trombocitopenia, hiperglobulinemia e hipoalbuminemia. Todas estas alterações estão presentes com grande frequência em pacientes que possuem as doenças promovidas por estes agentes, assim como relatados e devidamente justificadas em outros estudos (Stubbs et al. 2000, Aguirre et al. 2004, Sousa

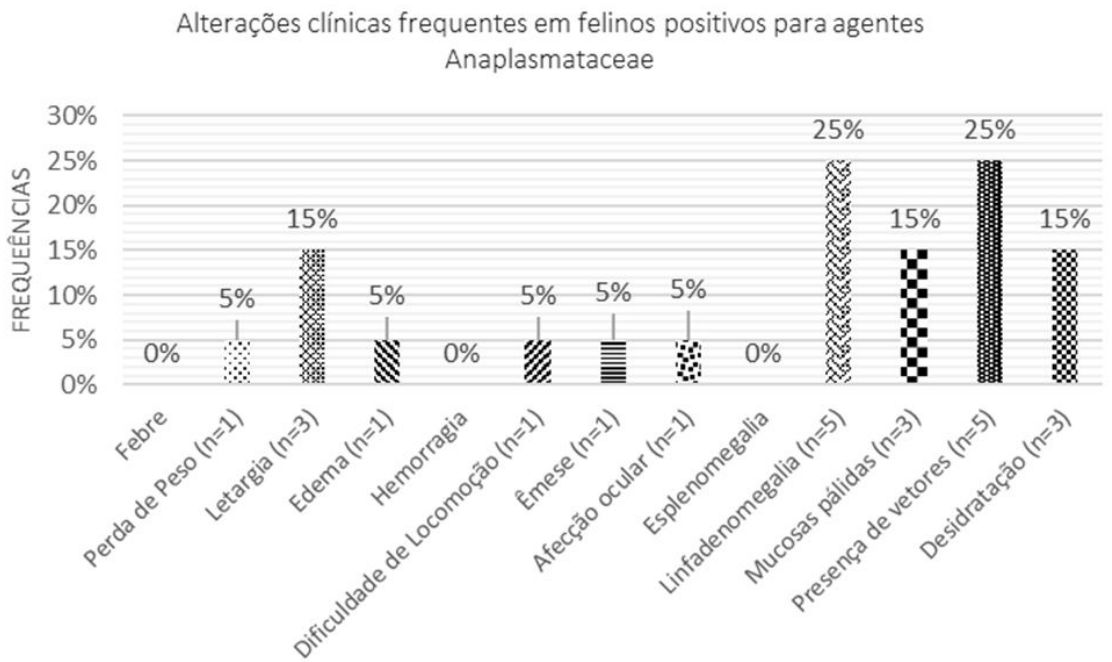

Fig.3. Alterações clínicas frequentes em felinos domésticos positivos em PCR para agentes da família Anaplasmataceae (n=20) em Campos dos Goytacazes, RJ.

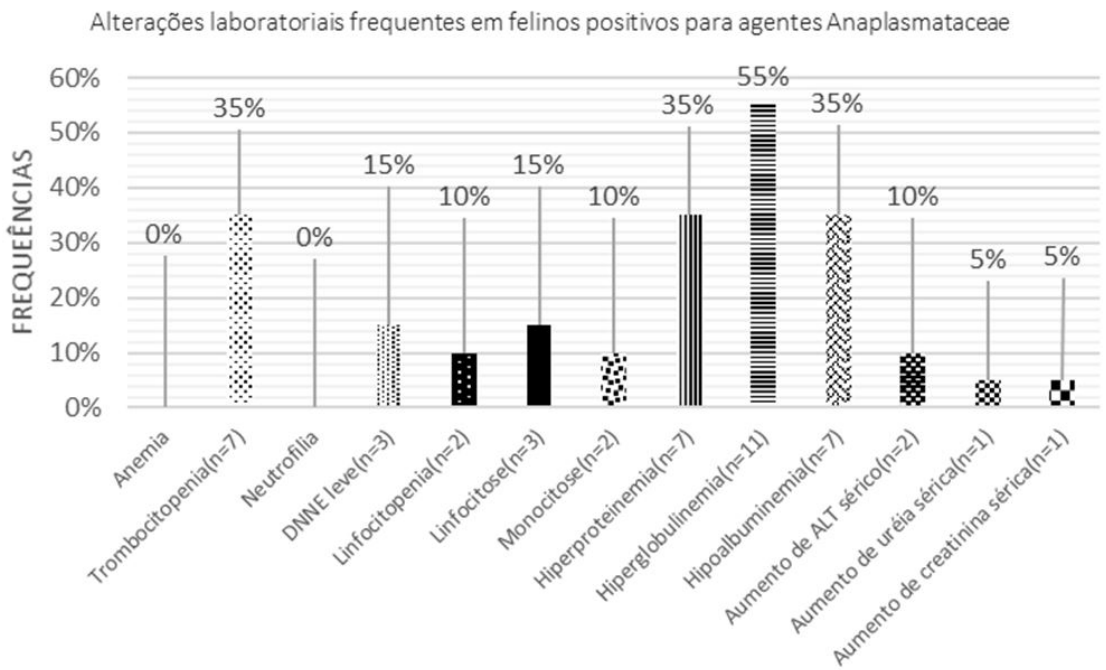

Fig.4. Alterações laboratoriais frequentes em felinos domésticos positivos em PCR para agentes da família Anaplasmataceae (n=20) em Campos dos Goytacazes, RJ. DNNE = desvio nuclear neutrofílico à esquerda, ALT = alanina aminotransferase. 
2006, Correa et al. 2011, Hergarty et al. 2015). Por esta grande frequência foi pertinente utilizar os dados clínicos-patológicos para verificação de uma correlação não paramétrica dos dados de felinos com estas alterações laboratoriais e a presença da infecção por algum agente desta família. Desta forma sendo importante verificar se estas determinadas alterações laboratoriais são independentes ou dependentes destas infecções (animais positivos na PCR para agentes da família Anaplasmataceae).

Logo abaixo se encontra o Quadro 1 que demonstra o teste Qui-quadrado utilizando os dados de globulinas, e no cálculo do Qui-quadrado foi verificado que não se rejeita a hipótese de que as variáveis ocorrem de forma independente. Desta forma, não se pôde confirmar se a alteração como hiperglobulinemia é dependente da presença de infecções em animais positivos na PCR para quaisquer agentes da família Anaplasmataceae. 0 quadro demonstra o planejamento do Qui-quadrado, e como considerações se pôde visualizar que o calculado $\left(\chi^{2} \mathrm{c}\right)$ possui o valor menor que o tabelado $\left(\chi^{2} \mathrm{t}\right)$, no nível de significância de $5 \%$.

0 Quadro 2 representa o teste Qui-quadrado utilizando os dados de albumina, e no cálculo do Qui-quadrado foi verificado que não se rejeita a hipótese de que as variáveis ocorrem de forma independente. Desta forma, não se pôde confirmar se a alteração como hipoalbuminemia é dependente da presença de infecções em animais positivos na PCR para quaisquer agentes da família Anaplasmataceae. Da mesma forma que a anterior o quadro demonstra o planejamento do Qui-quadrado, e como considerações se pôde visualizar que o calculado $\left(\chi^{2} \mathrm{c}\right)$ possui o valor menor que o tabelado $\left(\chi^{2} \mathrm{t}\right)$ no nível de significância de $5 \%$.

Já o Quadro 3 representa o teste Qui-quadrado utilizando os dados de contagem de plaquetas, e no cálculo do Qui-quadrado foi verificado que não se rejeita a hipótese de que as variáveis ocorrem de forma independente. Desta forma, não se pôde confirmar se a alteração como trombocitopenia é dependente da presença de infecção em animais positivos na PCR para quaisquer agentes da família Anaplasmataceae. Da mesma forma que a anterior, o quadro demonstra o planejamento do Qui-quadrado, e como considerações se pôde visualizar que o calculado $\left(\chi^{2} \mathrm{c}\right)$ possui o valor menor que o tabelado $\left(\chi^{2} t\right)$, no nível de significância de $5 \%$.

Como se pôde perceber, a análise destes dados revela que os dados de hiperglobulinemia, hipoalbuminemia e trombocitopenia são independentes da presença de animais positivos para algum agente da família Anaplasmataceae. Isso possivelmente pode ser consequência de que animais comprovadamente negativos também possuíram estas mesmas alterações laboratoriais. Portanto, apesar de entender que estas alterações apareçam em grandes proporções em animais positivos, estas mesmas não podem ser consideradas afirmativas de que os animais com tais alterações são considerados suspeitos diretamente para agentes Anaplasmataceae. Entretanto, percebe-se que estes dados têm caráter complementar, juntamente com dados clínicos no ato do atendimento, com outras alterações clínicas e laboratoriais, para se considerar que estes animais sejam suspeitos para a doença, até que se chegue a confirmação pelo diagnóstico por hematoscopia ou testes mais apurados como sorologia ou PCR.

Quadro 1. Número de gatos relacionados entre as variáveis, graus dos parâmetros para os níveis de globulina ( $\left.\mathrm{y}_{\mathrm{i}}\right)$ e grupos de animais, e os cálculos de Qui-quadrado

\begin{tabular}{|c|c|c|c|c|c|}
\hline \multirow[b]{2}{*}{ Grupos de animais $\left(\mathrm{x}_{\mathrm{i}}\right)$} & \multicolumn{3}{|c|}{ Graus dos parâmetros $\left(\mathrm{y}_{\mathrm{i}}\right)$} & \multirow[b]{2}{*}{$\chi^{2} \mathrm{c}$} & \multirow[b]{2}{*}{$\chi^{2} \mathrm{t}(\mathrm{p} \leq 5 \%)$} \\
\hline & $\begin{array}{c}\text { Normal } \\
(3,17-4,69 \mathrm{~g} / \mathrm{dl})\end{array}$ & $\begin{array}{c}\text { Lesão inicial } \\
(4,72-5,38 \mathrm{~g} / \mathrm{dl})\end{array}$ & $\begin{array}{c}\text { Lesão avançada } \\
(\geq 5,44 \mathrm{~g} / \mathrm{dl})\end{array}$ & & \\
\hline Controle & 6 & 4 & 6 & 3,25 & 9,48 \\
\hline Suspeitos negativos & 10 & 6 & 7 & & \\
\hline Suspeitos positivos & 4 & 8 & 9 & & \\
\hline
\end{tabular}

Quadro 2. Número de gatos relacionados entre as variáveis, graus dos parâmetros para os níveis de albumina ( $\left.\mathrm{y}_{\mathrm{i}}\right)$ e grupos de animais, e os cálculos de Qui-quadrado

\begin{tabular}{ccccc}
\hline & \multicolumn{4}{c}{ Graus dos parâmetros $\left(\mathrm{y}_{\mathrm{i}}\right)$} \\
\cline { 2 - 4 } Grupos de animais $\left(\mathrm{x}_{\mathrm{i}}\right)$ & $\begin{array}{c}\text { Lesão inicial } \\
(2,31-2,63 \mathrm{~g} / \mathrm{dl})\end{array}$ & $\begin{array}{c}\text { Lesão avançada } \\
(1,7-2,28 \mathrm{~g} / \mathrm{dl})\end{array}$ & $\chi^{2} \mathrm{c}$ & $\chi^{2} \mathrm{t}(\mathrm{p} \leq 5 \%)$ \\
\hline Controle & 7 & 9 & 8 & 6,28 \\
Suspeitos negativos & 8 & 6 & 9,48 & \\
Suspeitos positivos & 6 & 5 & 9
\end{tabular}

Quadro 3. Número de gatos relacionados entre as variáveis, graus dos parâmetros para os níveis de plaquetas ( $\mathrm{y}_{\mathrm{i}}$ ) e grupos de animais, e os cálculos de Qui-quadrado

\begin{tabular}{|c|c|c|c|c|c|}
\hline \multirow{2}{*}{$\begin{array}{l}\text { Grupos de animais } \\
\qquad\left(\mathrm{x}_{\mathrm{i}}\right)\end{array}$} & \multicolumn{3}{|c|}{ Graus dos parâmetros $\left(\mathrm{y}_{\mathrm{i}}\right)$} & \multirow[b]{2}{*}{$\chi^{2} \mathrm{c}$} & \multirow[b]{2}{*}{$\chi^{2} t(p \leq 5 \%)$} \\
\hline & $\begin{array}{c}\text { Normal } \\
\left(\geq 271 \times 10^{3} / \mu \mathrm{l}\right)\end{array}$ & $\begin{array}{c}\text { Lesão inicial } \\
\left(195-268 \times 10^{3} / \mu \mathrm{l}\right)\end{array}$ & $\begin{array}{c}\text { Lesão avançada } \\
\left(64-185 \times 10^{3} / \mu \mathrm{l}\right)\end{array}$ & & \\
\hline Controle & 4 & 5 & 7 & 2,29 & 9,48 \\
\hline Suspeitos negativos & 9 & 6 & 8 & & \\
\hline Suspeitos positivos & 5 & 9 & 7 & & \\
\hline
\end{tabular}


Alguns trabalhos procuraram realizar associações semelhantes para estas variáveis (Correa et al. 2011, Braga et al. 2013) e também verificaram que as variáveis não dependem da positividade do agente Anaplasmatacae. Portanto, entende-se que as alterações laboratoriais em felinos são consideradas achados inespecíficos. Little (2010) defende esta assertiva, explicando que o diagnóstico da ehrlichiose e anaplasmose se faz através da combinação dos dados avaliação clínica, histórico e, por fim, alterações laboratoriais para se suspeitar destas doenças, e por fim as análises necessárias e confirmatórias como presença de corpúsculos de inclusão ou mórulas, sorologia e PCR para a conclusão da suspeita clínica. Portanto, as alterações laboratoriais, exclusivamente, não são consideradas achados que comprovam a presença de algum agente, devendo ser consideradas somente achados complementares.

\section{CONCLUSÕES}

O melhor método para averiguação da epidemiologia de uma determinada população de felinos é através da obtenção de dados moleculares, ou seja, através da PCR. 0 teste sorológico é importante para determinação da epidemiologia da população, no entanto para avaliação da presença do agente, de forma individual, não é considerado fidedigno. A visualização de corpúsculo de inclusão pela hematoscopia é considerada de grande relevância no diagnóstico para Anaplasmataceae, apesar da baixa sensibilidade no diagnóstico.

A identificação dos agentes Ehrlichia canis e Anaplasma platys visa esclarecer a doença na região, da mesma forma sendo substancial para que seja instrumento de orientação da doença pelo médico veterinário ao proprietário para que tenha medidas adequadas de tratamento e prevenção. A presença de agentes Anaplasma phagocytophilum é considerada, sem dúvidas, uma notificação importante devido ao potencial zoonótico. Tal risco tem que ser estudado intensamente devido aos fatores biológicos existentes como vetores responsáveis pela transmissão, capacidade de inoculação e capacidade de infecção.

Neste contexto, a investigação do possível papel dos felinos domésticos na epidemiologia das doenças riquetsiais, é fundamental para a saúde pública, destarte, ações que visem a identificação de agentes causadores de enfermidades com potencial zoonótico, devem ser valorizadas.

Os dados clínico-laboratoriais são de suma importância para formação de animais suspeitos para a infecção, no entanto estes dados parcialmente não têm grande expressão para determinar a suspeita de doença para agentes Anaplasmataceae. É considerável que os dados laboratoriais sejam dados complementares para o diagnóstico para alguma doença promovida por estes agentes em felinos domésticos.

As principais alterações clínicas encontradas nos felinos com ehrlichiose ou anaplasmose foram letargia, linfadenomegalia, esplenomegalia, desidratação, perda de peso, edema, dificuldade de locomoção, êmese e afecção ocular.

\section{REFERÊNCIAS}

Aguirre E., Tesouro M.A., Amusategui I., Rodriguez-Franco F. \& Sainz A. 2004. Assessment of feline ehrlichiosis in central spain using serology and a polymerase chain reaction technique. Ann. N.Y. Acad. Sci. 1026(1):103-105. http://dx.doi.org/10.1196/annals.1307.013. PMid:15604476.
Almosny N.R.P. 1998. Ehrlichia canis (Donatien and Lestoquard 1935): avaliação parasitológica, hematológica e bioquímica sérica da fase adulta de cães e gatos experimentalmente infectados. Tese de Doutorado em Parasitologia, Universidade Federal Rural do Rio de Janeiro, Seropédica, RJ. 202p.

Alves L.M., Linhares G.F.C., Chaves N.S.T., Monteiro L.C. \& Linhares D.C. 2005. Avaliação de iniciadores e protocolo para o diagnóstico da pancitopenia tropical canina por PCR. Ciênc. Anim. Bras. 6:49-54.

André M.R., Herrera H.M., Fernandes S.J., Souza K.C.M., Gonçalves L.R., Domingos I.H., Macedo G.C. \& Machado R.Z. 2015. Tick-borne agentes in domesticated and stray cats from the city of Campo Grande, state of Mato Grosso do Sul, midwestern Brazil. Ticks Tick Borne Diseases 6(6):779786. http://dx.doi.org/10.1016/j.ttbdis.2015.07.004. PMid:26187416.

Ayllon T., Villaescusa A., Tesouro M.A. \& Sainz A. 2009. Serology, PCR and culture of Ehrlichia/Anaplasma species in assymptomatic and symptomatic cats from central Spain. Clin. Microbiol. Infect. 15(Suppl. 2):4-5. http:// dx.doi.org/10.1111/j.1469-0691.2008.02645.x. PMid:19374640.

Bakken J.S. \& Dumler S. 2008. Human granulocytic anaplasmosis. Infect. Dis. Clin. N. Am. 22(3):433-448, viii. http://dx.doi.org/10.1016/j.idc.2008.03.011. PMid:18755383.

Bergmann M., Englert T., Stuetzer T., Hawley J.R., Lappin M.R. \& Hartmann K. 2015. Prevalence of selected rickettsial infections in cats in Southern Germany. Comp. Immunol. Microbiol. Infect. Dis. 42:33-36. http://dx.doi. org/10.1016/j.cimid.2015.08.003. PMid:26387062.

Billeter S.A., Spencer J.A., Griffin B., Dykstra C.C. \& Blagburn B.L. 2007. Prevalence of Anaplasma phagocytophilum in domestic felines in the United States. Vet. Parasitol. 147(1/2):194-198. http://dx.doi.org/10.1016/j. vetpar.2007.03.028. PMid:17493756.

Birkenheuer A.J., Levy M.G. \& Breitschwerdt E.B. 2003. Development and evaluation of a seminested PCR for detection and differentiation of Babesia gibsoni (Asian genotype) and B. Canis DNA in canine blood samples. J. Clin. Microbiol. 41(9):4172-4177. http://dx.doi.org/10.1128/JCM.41.9.41724177.2003. PMid:12958243.

Bjöersdorff A., Svendenius L., Owens J.H. \& Massung R.F. 1999. Feline granulocytic ehrlichiosis: a report of a new clinical entity and characterisation of the infectious agent. J. Small Anim. Pract. 40(1):20-24. http://dx.doi. org/10.1111/j.1748-5827.1999.tb03249.x. PMid:10092038.

Bouloy R.P., Lappin M.R., Holland C.H., Thrall M.A., Baker D. \& O'neil S. 1994. Clinical ehrlichiosis in a cat. J. Am. Vet. Med. Assoc. 204(9):1475-1478. PMid:8050974.

Braga M.S.C.O., André M.R., Freschi C.R., Teixeira M.C.A. \& Machado R.Z. 2012. Molecular and serological detection of Ehrlichia spp. in cats on São Luís Island, Maranhão, Brazil. Revta Bras. Parasitol. Vet. 21(1):37-41. http:// dx.doi.org/10.1590/S1984-29612012000100008. PMid:22534943.

Braga I.A., Santos L.G.F., Melo A.L.T., Jaune F.W., Ziliani T.F., Girardi A.F. \& Aguiar D.M. 2013. Hematological values associated to the serological and molecular diagnostic in cats suspected of Ehrlichia canis infection. Revta Bras. Parasitol. Vet. 22(4):470-474. http://dx.doi.org/10.1590/S198429612013000400005. PMid:24473870.

Braga I.A., Santos L.G.F., Ramos D.G.S., Melo A.L.T., Mestre G.L.C. \& Aguiar D.M. 2014. Detection of Ehrlichia canis in domestic catsin the central-western region of Brazil. Revta Bras. Parasitol. Vet. 45(2):641-645. PMid:25242952.

Breitschwerdt E.B., Abrams-Ogg A.C., Lappin M.R., Bienzle D., Hancock S.I., Cowan S.M., Clooten J.K., Hegarty B.C. \& Hawkins E.C. 2002. Molecular evidence supporting Ehrlichia canis-like infection in cats. J. Vet. Intern. Med. 16(6):642-649. PMid:12465759.

Carrade D.D., Foley J.E., Borjesson D.L. \& Sykes J.E. 2009. Canine granulocytic anaplasmosis: a review. J. Vet. Intern. Med. 23(6):1129-1141. http://dx.doi. org/10.1111/j.1939-1676.2009.0384.x. PMid:19761477.

Correa E.S., Paludo G.R., Scalon M.C., Machado J.A., Lima A.C.Q., Pinto A.B.T., Thiebaut J.T.L. \& Albernaz A.P. 2011. Investigação molecular de Ehrlichia spp. e Anaplasma platys em felinos domésticos: alterações clínicas, 
hematológicas e bioquímicas. Pesq. Vet. Bras. 31(10):899-909. http:// dx.doi.org/10.1590/S0100-736X2011001000011.

D’Agnone A.S. 2006. Caracterização molecular de espécies da família Anaplasmataceae em leucócitos e plaquetas de cães de Jaboticabal/SP e de Campo Grande/MS. Tese de Doutorado, Faculdade de Ciências Agrárias e Veterinárias, Universidade Estadual Paulista, Campus de Jaboticabal, SP. 141p.

Dawson J.E., Ewing S.A. \& Davidson W.R. 2005. Human monocytotropic ehrlichiosis, p.239-257. In: Goodman J.L., Dennis D.T. \& Sonenshine D.E. (Eds), Tick-borne Diseases of Humans. ASM Press, Washington, DC. http:// dx.doi.org/10.1128/9781555816490.ch14.

Doyle C.K., Labruna M.B., Breitschwerdt E.B., Tang Y.W., Corstvet R.E., Hegarty B.C., Bloch K.C., Li P., Walker D.H. \& McBride J.W. 2005. Detection of medically important Ehrlichia by quantitative multicolor TaqMan Real-Time Polymerase Chain Reaction of the DSB Gene. J. Mol. Diagn. 7(4):504-510. http://dx.doi.org/10.1016/S1525-1578(10)60581-8. PMid:16237220.

Dumler J.S., Madigan J.E., Pusterla N. \& Bakken J.S. 2007. Ehrlichiosis in humans: epidemiology, clinical presentation, diagnosis, and treatment. Clin. Infect. Dis. 45(Suppl. 1):45-51. http://dx.doi.org/10.1086/518146.

Dumler J.S., Barbet A.F., Bekker C.P.J., Dasch G.A., Palmer G.H., Ray C.R., Rikihisa Y. \& Rurangirwa F.R. 2001. Reorganization of genera in the families Rickettsiaceae and Anaplasmataceae in the order Rickettsiales: unification of some species of Ehrlichia with Anplasma, Cowdria with Ehrlichia and Ehrlichia with Neorickettsia, descriptions of six new species combinations and designation of Ehrlichia equi and 'HE agent' as subjective synonyms of Ehrlichia phagocytophila. Int. J. Syst. Evol. Microb. 51(Pt 6):2145-2165. http://dx.doi.org/10.1099/00207713-51-6-2145. PMid:11760958.

Ebani V.V. \& Bertelloni F. 2014. Serological evidence of exposure to Ehrlichia canis and Anaplasma phagocytophilum in Central Italian healthy domestic cats. Ticks Tick Borne Diseases 5(6):668-671. http://dx.doi.org/10.1016/j. ttbdis.2014.04.019. PMid:25113987.

Ferreira R.R., Cerqueira A.M.F., Pereira A.M., Velho P.B., Azevedo R.M.M., Rodigues I.L.F. \& Almosny N.R.P. 2008. Avaliação da ocorrência de reação cruzada em cães PCR-positivos para Anaplasma platys testados em ELISA comercial para detecção de anticorpos de Anaplasma phagocytophilum. Revta Bras. Parasitol. Vet. 17(1):5-8.

Gaunt S., Beall M., Stillman B., Lorentzen L., Diniz P., Chandrashekar R. \& Breitschwerdt E. 2010. Experimental infection and co-infection of dogs with Anaplasma platys and Ehrlichia canis: hematologic, serologic and molecular findings. Parasit. Vectors 3(1):33. http://dx.doi.org/10.1186/1756-33053-33. PMid:20377870.

Harrus S. \& Waner T. 2011. Diagnosis of canine monocytotropic ehrlichiosis (Ehrlichia canis): an overview. Vet. J. 187(3):292-296. http://dx.doi. org/10.1016/j.tvjl.2010.02.001. PMid:20226700.

Harvey J.W. 2012. Anaplasma platys infection (Thrombocytotropic Anaplasmosis), p.256-258. In: Greene G.E. (Ed.), Infectious Diseases of the Dog and Cat. 4 th ed. Elsevier Saunders, St Louis.

Hergarty B.C., Qurollo B.A., Thomas B., Park K., Chandrashekar R., Beall M.J., Thatcher B. \& Breitschwerdt E.B. 2015. Serological and molecular analysis of feline vector-borne anaplasmosis and ehrlichiosis using speciesespecific peptides and PCR. Parasit. Vectors 8(1):320-328. http://dx.doi. org/10.1186/s13071-015-0929-8. PMid:26062723.

Heikkilä H.M., Bondarenko A., Mihalkov P., Pfister K. \& Spillmann T. 2010. Anaplasma phagocytophilum infection in a domestic cat in Finland: case report. Acta Vet. Scand. 52(1):62-66. http://dx.doi.org/10.1186/17510147-52-62. PMid:21078141.

IBGE 2015. População de animais de estimação no Brasil em 2013. Elaboração Associação Brasileira da Indústria de Produtos para Animais de Estimação (Abinpet), 79ạ Reunião Ordinária, Auditório Maior, MAPA, Brasília/DF. 7p.

Inokuma A., Fujii K., Matsumoto K., Okuda M., Nakagome K., Kosugi R., Hirakawa M. \& Onishi T. 2002. Demonstration of Anaplasma (Ehrlichia) platys inclusions in peripheral blood platelets of a dog in Japan. Vet. Parasitol.
110(1-2):145-152. http://dx.doi.org/10.1016/S0304-4017(02)00289-3 PMid:12446100

Inokuma H., Raoult D. \& Brouqui P. 2000. Detection of Ehrlichia platys DNA in brown dog ticks (Rhipicephalus sangineus) in Okinawa Island. Jpn. J. Clin. Microbiol. 38(11):4219-4221. PMid:11060094.

Kidd L. \& Breitschwerdt E.B. 2003. Transmission times and prevention of tick-borne diseases in dogs. Comp. Cont. Educ. Pract. Vet. 25:742-775.

Lappin M.R. \& Breitschwerdt E.B. 2012. Ehrlichia spp. infection (feline monocytotropic ehrlichiosis), p.238-241. In: Greene C.E. (Ed.), Infectious Diseases of the Dog and Cat. 4th ed. Elsevier Saunders, St Louis.

Lappin M.R., Breitschwerdt E.B., Jensen W.A., Dunningan B., Rha J.Y., Williams C.R., Brewer M. \& Fall M. 2004. Molecular and serologic evidence of Anaplasma phagocytophilum infection in cats in North America. J. Am. Vet. Med. Assoc. 225(6):893-896, 879. http://dx.doi.org/10.2460/javma.2004.225.893. PMid:15485049.

Lima M.L.F., Soares P.T., Ramos C.A.N., Araújo F.R., Ramos R.A.N., Souza I.I.F., Faustino M.A.G. \& Alves L.C.A. 2010. Molecular detection of Anaplasma platys in a naturally-infected cat in Brazil. Braz. J. Microbiol. 41(2):381-385 http://dx.doi.org/10.1590/S1517-83822010000200019. PMid:24031508.

Little S.E. 2010. Ehrlichiosis and anaplasmosis in dogs and cats. Vet. Clin. N. Am., Small Anim. Pract. 40(6):1121-1140. http://dx.doi.org/10.1016/j. cvsm.2010.07.004. PMid:20933140.

Magnarelli L.A., Bushmich S.L., Ijdo J.W. \& Fikrig E. 2005. Seroprevalence of antibodies against Borrelia burgdorferi and Anaplasma phagocytophilum in cats. Am. J. Vet. Res. 66(11):1895-1899. http://dx.doi.org/10.2460/ ajvr.2005.66.1895. PMid:16334946.

Maia C., Ramos C., Coimbra M., Bastos F., Martins A., Pinto P., Nunes M., Vieira M.L., Cardoso L. \& Campino L. 2014. Bacterial and protozoal agentes of feline vector-borne diseases in domestic and stray cats from Southern Portugal. Parasit. Vectors 7(1):115-122. http://dx.doi.org/10.1186/17563305-7-115. PMid:24655431.

Martin A.R., Brown G.K., Dunstan R.H. \& Roberts T.K. 2005. Anaplasma platys: an improved PCR for its detection in dogs. Exp. Parasitol. 109(3):176-180 http://dx.doi.org/10.1016/j.exppara.2004.11.007. PMid:15713449.

Murphy G.L., Ewing S.A., Whitworth L.C., Fox J.C. \& Kocan A.A. 1998. A molecular and serologic survey of Ehrlichia canis, E. chaffeensis and E. ewingii in dogs and ticks from Oklahoma. Vet. Parasitol. 79(4):325-339.

Mylonakis M.E., Koutinas A.F., Billinis C., Leontides L.S., Kontos V., Papadopoulos O., Rallis T. \& Fytianou A. 2003. Evaluation of cytology in the diagnosis of acute canine monocytic Ehrlichiosis (Ehrlichia canis): a comparison between five methods. Vet. Microbiol. 91(2/3):197-204. http://dx.doi. org/10.1016/S0378-1135(02)00298-5. PMid:12458168.

Oliveira L.S. 2008. Investigação molecular de Ehrlichia em uma população de cães e gatos em Viçosa/MG. Dissertação de Mestrado em Medicina Veterinária, Universidade Federal de Viçosa, Viçosa, MG. 75p.

Oliveira L.S., Mourão L.C., Oliveira K.A., Agostini M.M., Oliveira A.C., Almeida M.R., Fietto J.L.R., Conceição L.G., Filho J.D.R., Galvão M.A.M. \& Mafra C. 2009. Molecular detection of Ehrlichia canis in cats in Brazil. Braz. J. Microbiol. 15(2, Suppl. 2):53-54. PMid:19374643.

Ortuño A., Gauss C.B.L., Garcia F. \& Gutierrez J.F. 2005. Serological evidence of Ehrlichia spp. exposure in cats from Northeastern Spain. J. Vet. Med. B, Infect. Dis. Vet. Public Health 52(5):246-248. http://dx.doi.org/10.1111/j.14390450.2005.00849.x. PMid:16115100.

Ramos C.A.N., Ramos R.A.N., Araújo F.R., Guedes Junior J.R.D., Souza I.I.F., Ono T.M., Vieira A.S., Pimentel D.S., Rosas E.O., Faustino M.A.G. \& Alves L.C 2009. Comparação de nested-PCR com o diagnóstico direto na detecção de Ehrlichia canis e Anaplasma platys em cães. Revta Bras. Parasitol. Vet. 18(Supl. 1):58-62. http://dx.doi.org/10.4322/rbpv.018e1011. PMid:20040193.

Santarém V.A., Laposy C.B. \& Farias M.R. 2005. Anaplasma platys (Ehrlichia platys)-like inclusion bodies in platelets of a cat. Colloquium Agrariae 1(2):60-66. http://dx.doi.org/10.5747/ca.2005.v01.n2.a015. 
Sasaki H., Ichikawa Y., Sakata Y., Endo Y., Nishigaki K., Matsumoto K. \& Inokuma H. 2012. Molecular survey of Rickettsia, Ehrlichia and Anaplasma infection of domestic cats in Japan. Ticks Tick Borne Diseases 3(5/6):307-310. http:// dx.doi.org/10.1016/j.ttbdis.2012.10.028. PMid:23168051.

Savidge C., Ewing P., Andrews J., Aucoin D., Lappin M.R. \& Moroff S. 2015. Anaplasma phagocytophilum infection of domestic cats: 16 cases from the northeastern USA. J. Feline Med. Surg. 18(2):85-91. http://dx.doi. org/10.1177/1098612X15571148. PMid:25680735.

Silveira J.A.G., Valente P.C.L.G., Paes P.R.O., Vasconcelos A.V., Silvestre B.T. \& Ribeiro M.F.B. 2015. The first clinical and laboratory evidence of co-infection by Anaplasma phagocytophilum and Ehrlichia canis in a Brazilian dog. Ticks Tick Borne Diseases 6(3):242-245. http://dx.doi.org/10.1016/j. ttbdis.2015.01.003. PMid:25661650.

Solano-Gallego L., Hegarty B., Espada Y., Llull J. \& Breitschwerdt E. 2006. Serological and molecular evidence of exposure to arthropod-borne organisms in cats from northeastern Spain. Vet. Microbiol. 118(3/4):274277. http://dx.doi.org/10.1016/j.vetmic.2006.07.010. PMid:16919405.

Sousa V.R.F. 2006. Avaliação clínica, morfológica, hematológica, bioquímica e biomolecular e cães naturalmente infectados por Ehrlichia canis e Anaplasma platys. Tese de Doutorado, Universidade Federal Rural do Rio de Janeiro, Seropédica, RJ. 58p.

Spada E., Proverbio D., Galluzzo P., Della Pepa A., Perego P., De Giorgi G.B. \& Ferro E. 2014. Molecular study on selected vector-borne infections in urban stray colony cats in northen Italy. J. Feline Med. Surg. 16(8):684688. http://dx.doi.org/10.1177/1098612X13514422. PMid:24319060.
Stubbs C.J., Holland C.J. \& Reif J.S. 2000. Feline ehrlichiosis. Comp. Cont. Educ. Pract. Vet. 22:307-317.

Tarello W. 2005. Microscopic and clinical evidence for Anaplasma (Ehrlichia) phagocytophilum infection in Italian cats. Vet. Rec. 156(24):772-774. http:// dx.doi.org/10.1136/vr.156.24.772. PMid:15951500.

Waner T., Harrus S., Jongejan F., Bark H., Keysary A. \& Cornelissen A.W. 2001. Significance of serological testing for ehrlichial diseases in dogs with special emphasis on the diagnosis of canine monocytic ehrlichiosis caused by Ehrlichia canis. Vet. Parasitol. 95(1):1-15. http://dx.doi.org/10.1016/ S0304-4017(00)00407-6. PMid:11163693.

Yamanaka A.R., Benetti A.H., Darold G.M., Igarashi M., Muraro L.S., Alarcon L.F., Moura S.T., Dutra A.A. \& Gazeta G.S. 2014. Soroprevalência de Anaplasma Phagocytophilum em felinos domésticos atendidos no hospital veterinário da Universidade de Cuiabá/MT. Anais 35º Congresso Brasileiro da Anclivepa, Belo Horizonte, MG.

Zeidner N.S., Dolan M.C., Massung R., Piesman J. \& Fish D. 2000. Coinfection with Borrelia burgdorferi and the agent of human granulocytic ehrlichiosis suppresses IL-2 and IFNg production and promotes an IL-4 response in C3H/HeJ mice. Parasite Immunol. 22(11):581-588. http://dx.doi. org/10.1046/j.1365-3024.2000.00339.x. PMid:11116438.

Zobba R., Anfossi A.G., Visco S., Sotgiu F., Dedola C., Pinna Parpaglia M.L., Battilani M., Pittau M. \& Alberti A. 2015. Cell tropismo and molecular epidemiology of Anaplasma platys-like strains in cats. Ticks Tick Borne Diseases 6(3):272-280. http://dx.doi.org/10.1016/j.ttbdis.2015.01.008. PMid:25682496. 